\title{
Efficacy of newer molecules of insecticides against white grub in sugarcane
}

\section{PRADNYA B. MANE AND PANDURANG B. MOHITE}

Division of Entomology, Mahatma Phule Krishi Vidyapeeth, College of Agriculture, KOLHAPUR (M.S.) INDIA

A field experiment comprised of seven insecticides was conducted at farmers field in endemic area of pest in Kolhapur district particularly area nearby riverbank during 2009-2010. The application of newer insecticides was done by drenching and the granules were applied along with dry soil. Soil drenching of imidacloprid 40 per cent + fipronil 40 per cent - 80 WG @ $300 \mathrm{~g} \mathrm{ha}^{-1}$ was found to be most effective treatment for control of white grub followed by clothianidin 50 WDG @ $250 \mathrm{~g} \mathrm{ha}^{-1}$, flubendiamide $480 \mathrm{SC} @ 400 \mathrm{ml} \mathrm{ha}^{-1}$ and rynaxypyr 0.4 per cent G@125 $\mathrm{g} \mathrm{ha}^{-1}$.

Key words : Imidacloprid, Clothianidin, Flubendiamide, Rynaxypyr, Sugarcane

How to cite this paper : Mane, Pradnya B. and Mohite, Pandurang B. (2014). Efficacy of newer molecules of insecticides against white grub in sugarcane. Asian J. Bio. Sci., 9 (2) : 173-177. 